\title{
Classifying Social Enterprises Through Theoretical Typologies to Understand Social Innovation
}

\author{
Marcelo T Okano ${ }^{1}$, Lidia Felix Iamanaka ${ }^{1}$, Rosinei Batista Ribeiro ${ }^{1}$, Celi Langhi ${ }^{1} \&$ Marcelo Eloy Fernandes $^{1}$ \\ ${ }^{1}$ CETTEPS and FT-UNICAMP, Brazil \\ Correspondence: Marcelo T Okano, CETTEPS and FT-UNICAMP, Brazil.
}

Received: February 5, 2021

Accepted: March 17, 2021

Online Published: November 8, 2021

doi:10.5430/ijba.v12n6p1

URL: https://doi.org/10.5430/ijba.v12n6p1

\begin{abstract}
In the latter, there has been an increasing importance attributed to the measurement of social value and social impact that various organizations create. The demand to measure this value comes from all sides: funders who want to direct their money to the most effective projects, policy makers and government officials must be accountable for their spending decisions, and social organizations need to demonstrate their impact to financiers, partners and beneficiaries. This article intends to classify social companies through theoretical types and analyze their characteristics to understand social innovation. The first stage of the project was the elaboration of the theoretical framework on the themes of social enterprise, typology of social enterprises, social business model and social innovation. The research instrument was an interview guide, and the next step was to select three social companies of different types to carry out the empirical research. These typologies were tested in three social companies in the empirical research and the effectiveness of the typologies was proven.
\end{abstract}

Keywords: social enterprises, theoretical typologies, social innovation, business model

\section{Introduction}

The concept of value proposition, added value, competitive advantage and other terms refer to the forms of values that the customer perceives when purchasing or receiving a product, service or solution. In the past, the perceived value was economic or financial, but today, different forms of values become significant such as status, social, pleasure and so on.

According to Mulgan (2010), there is no single and authorized definition of "social value", but we can say that it refers to broader non-financial impacts of programs, organizations and interventions, including the well-being of individuals and communities, social capital and the environment.

These social changes require companies to operate in a network. For this, stakeholders must form interorganizational networks that allow cooperation and commitment in relationships, generating economic and social gains (Okano, 2017).

In the latter, there has been an increasing importance attributed to the measurement of social value and social impact that various organizations create. The demand to measure this value comes from all sides: funders who want to direct their money to the most effective projects, policy makers and government officials must be accountable for their spending decisions, and social organizations need to demonstrate their impact to financiers, partners and beneficiaries (Mulgan, 2010).

These actions carried out by these organizations with economic and social objectives, called social companies or social enterprises, create a type of social innovation (SI). To generate social change, the concept of innovation should create opportunities for the improvement of living conditions, aiming at a more fraternal society, in addition to covering gaps where the public power is unable to meet (Okano, 2017; de Oliveira, da Silva, 2012).

According to Sunio et al. (2020) in the past decade, there has emerged a new organizational form, called social enterprise that combines the logics of profit and social purpose. These organizations have the aptitude to create financial and social value, and for that, it is necessary to create business models that enable the simultaneous execution of both objectives (Tykkyläinen \& Ritala, 2021). 
Business models are important for all types of companies and other forms of organizations, such as social companies, as they are an important source of survival, value creation and competitive advantage for companies (Bocken, 2021).

This article intends to classify social companies through theoretical types and analyze their characteristics to understand social innovation.

This article has five sections, this being the first. The others are section 2 presents the concepts and definitions related to the subjects treated in this work as social companies, types of social companies and social innovation. Section 3 presents the ways to conduct the field research. Section 4 presents the main results for discussion and interpretation and section 5 is dedicated to the end of the work and recommendations for the continuity of the work.

\section{Theoretical Foundation}

This section presents theories on social enterprises, types of social enterprises and social innovation.

\subsection{Social Enterprise (ES)}

Due to the promotion of the Italian cooperative movement, the concept of social enterprise emerged in Europe in 1990, with the term "social cooperative". The initial objective of these companies was to provide low-cost services to the public sector and create jobs for marginalized and unemployed people. (Borzaga and Defourny, 2001).

Social enterprises are different from conventional organizations, whether they are for profit or not. In particular, the profit-seeking aspects of a social enterprise make individuals skeptical of its prosocial purpose (Choi et al., 2020)

Okano (2020B) presents in the article "Bibliometric analysis of social enterprises: what is their impact on academic production?" various definitions of social enterprises and shows that there is no consensus on the subject. From the definitions presented, two were selected that represent the best definitions of Social Enterprise according to the authors of this article:

- "The social enterprise is a form of organization with social motivators that carries out innovative business operations to support itself and guarantees the creation, sustainability, distribution and / or dissemination of social or environmental value. Therefore, economic drivers are means to a social end, not the end itself (Granados et al., 2001)".

- "Social enterprises are organizations that seek to address social issues through the application of business practices and principles (Dacin et al., 2010)".

In proposing these definitions, the authors believe that the objectives or missions of these companies are social, the structure is the company or business organization and must be profitable. Some characteristics specific to this type of business are presented below:

a) Economic and social market - the market of a social enterprise does not refer only to sales revenue but develops from market principles and philanthropic principles in terms of motives, methods and objectives, most social companies combine commercial and philanthropic elements in a productive balance (Dees, 1998).

b) Mission and objective - the mission of social companies differs from those proposed by conventional companies that aim to maximize profits (Defourny and Nyssens, 2017).

c) Profit - in the social enterprises, the main thing is not to maximize the financial returns of the shareholders, but to expand the social enterprise and reach more people in need, the accumulation of wealth is not a priority, and the profits must be reinvested in the company to finance the expansion (Buchko, 2018).

\subsection{Types of Social Enterprises}

The importance of ES typologies, according to Defourny and Nyssens (2017), is to precisely identify distinctive characteristics of ES, showing how the combinations of all or some of these characteristics can be diverse. Bibliographic review indicates that the potential of a social enterprise can be verified from its typology. Thus, it is possible to classify these companies according to their origin, objectives, trajectory, type, profit orientation, mission orientation, nature of the target market and their degree of integration in social programs, as shown in Figure 1. 


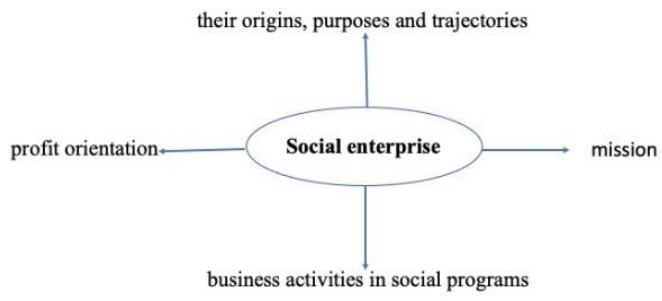

Figure 1. Types of social enterprises

Source: Authors

\subsubsection{Types of Social Enterprises According to the Profit Orientation}

For Alter (2007), the typology according to the profit orientation there is a basic premise called spectrum, as shown in Figure 2. The changing expectations of nonprofit stakeholders to achieve a larger scale social impact and, at the same time, diversifying its financing was credited as an important factor in the appearance of the "hybrid non-profit" part for profit and non-profit part. This intersection of traditional nonprofit businesses is where the social enterprise is.

\section{Hybrid Spectrum}

\begin{tabular}{|c|c|c|c|c|c|}
\hline $\begin{array}{c}\text { Traditional } \\
\text { Nonprofit }\end{array}$ & $\begin{array}{c}\text { Nonprofit } \\
\text { With income- } \\
\text { Generating } \\
\text { Activities }\end{array}$ & $\begin{array}{c}\text { Social } \\
\text { Enterprise }\end{array}$ & $\begin{array}{c}\text { Socially } \\
\text { Responsible } \\
\text { Business }\end{array}$ & $\begin{array}{c}\text { Corporation } \\
\text { Practicing } \\
\text { Social } \\
\text { Responsibility }\end{array}$ & $\begin{array}{c}\text { Traditional } \\
\text { For-Profit }\end{array}$ \\
& & & \\
\hline
\end{tabular}

Figure 2. Hybrid spectrum

Source: Alter (2007)

All hybrid organizations generate social and economic value and are organized by degree of activity regarding a) motivation, b) accountability and c) use of income. The hybrid spectrum includes four types of hybrid practitioners: non-profit organizations, social enterprise, socially responsible businesses and corporation practicing social responsibility. Income generation activities are not conducted as a separate business but are integrated with the other activities of the organization, which involve little revenue in relation to the organization's general budget and traditional fundraising contributions. The spectrum of practitioners can be seen in Table 1 .

Social enterprises are defined as any commercial enterprise created for social purposes, mitigating / reducing a social problem or a market failure and to generate social value while operating with the financial discipline, innovation and determination of a private sector business. Socially responsible businesses are for-profit companies that operate for dual purposes - profiting from their shareholders and contributing to a broader social good. Corporations that practice social responsibility are for-profit companies whose motives are financially motivated but are involved in philanthropy. "Strategic philanthropy" helps companies achieve the goals of maximizing profit and market share, contributing to the public good.

Table 1. Spectrum of practitioners

\begin{tabular}{llll}
\hline & Purely philanthropic & Hybrid & Purely commercial \\
\hline Reasons & Appeal to goodwill & Mixed motives & Appeal to self-interest \\
\hline Methods & Mission oriented & Balance of mission and market & Driven by the market \\
\hline
\end{tabular}




\begin{tabular}{|c|c|c|c|}
\hline Goals & Creating social value & Creating social and economic value & Creating economic value \\
\hline $\begin{array}{l}\text { Destination of } \\
\text { income / profit }\end{array}$ & $\begin{array}{l}\text { Targeted to nonprofit } \\
\text { mission activities } \\
\text { (required by law or } \\
\text { organizational policy) }\end{array}$ & $\begin{array}{l}\text { Reinvested in mission activities or } \\
\text { operating expenses and / or retained for } \\
\text { business growth and development (the } \\
\text { organization may redistribute a } \\
\text { portion) }\end{array}$ & $\begin{array}{l}\text { Distributed to shareholders } \\
\text { and owners }\end{array}$ \\
\hline
\end{tabular}

Source: Alter (2007)

Buchko (2018) complements Alter's spectrum (2007) and classifies social companies according to the profit orientation: for-profit (for-profit area) and non-profit (non-profit area) companies, according to Figure 3. In social enterprises, the main objective is not to maximize shareholder financial returns, but to expand the social enterprise and reach more people in need, and wealth accumulation is not a priority, and profits must be reinvested in the company to finance expansion (Buchko, 2018).

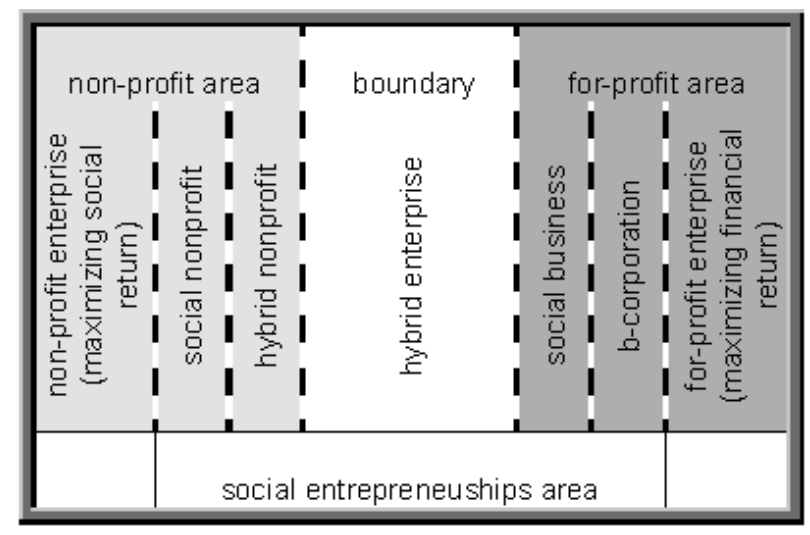

Figure 3. Social enterprises and their limits

Source: Buchko, 2018

Social enterprises develop in a commercial, non-profit way, but there are also hybrid models (Buchko, 2018):

a) The starting point of social enterprises happens in a non-profit way seeking to maximize the social impact, the central nucleus of the non-profit social enterprise being the expenditure of funds available to meet social needs, whether these funds come from philanthropy or donations.

b) The non-profit hybrid company uses its available funds to support the operations of its own business, these funds coming from donation or philanthropy. Here associations and foundations can be found.

c) The hybrid company is a mixture of the non-profit model and the profit model, being more financially self-sufficient compared to the previous one, and the available funds are spent according to social goals, but from time to time reinvests its profits, because there are commercial activities involved.

d) Social businesses carry out social and commercial business activities at the same time, they are self-sustainable and more financially independent, thus being a profitable company contributing to a social good. Here social cooperatives can be found.

e) "B-corporation" (or Benefit Corporation), its owners are interested in maximizing the financial return, but the company has a social function. It is a profit-oriented company that wants to consider other stakeholders in the business, in addition to bringing profit to its shareholders.

Profit-oriented typologies are not simply profit-making and non-profit organizations, as the dual social and economic mission often requires the organization to adapt to the rules of the type of organization. An example is the social business of the company, which must be profitable in order to be self-sustainable, but the profit must be reinvested in the organization itself and not be shared with the partners. This leads to the appearance of new forms of social 
companies such as hybrid companies, Bcorps and those that can be created as social tech, forcing new updates to the typologies.

\subsubsection{Types of Social Enterprises According to Business Activities in Social Programs}

Alter (2007) focuses on the place and role of market logics to propose a typology based on mission orientation, the nature of the target markets and the degree of integration of business activities in social programs.

As for the mission, in hybrid organizations, financial and social goals are often in opposition or competition with each other. Mission-centered, mission-related and non-mission-related social enterprises are:

a) Mission-Centered Social Enterprise - The company is central to the organization's social mission. These social companies are created with the express purpose of advancing the mission using a self-financing model.

b) Mission-Related Social Enterprise - The company is related to the organization's mission or essential social services.

c) Social enterprise unrelated to the mission - The undertaking is not related to the organization's mission or is intended to advance the mission unless it generates income for its social programs and operating costs.

Business / program integration indicates that social enterprises can be classified based on the level of integration between social programs and business activities:

a) Incorporated social enterprises: the social programs and business activities are the same.

b) Integrated social companies: social programs overlap with business activities, sharing costs and assets.

c) External social companies whose social programs are distinct from business activities.

\subsubsection{Types of Social Enterprises According to Their Origins, Purposes and Trajectories}

Based on field observations, Defourny and Nyssens (2017) propose typologies based on the combination of aspects such as origins, purposes, trajectories and discourses of social companies.

1. In third sector companies, with economic initiatives oriented towards social objectives, it is common to find these types of combinations. It is also possible to identify two distinct profiles in this type of company:

A. Commercial charity - which, given their social mission, emphasize obtaining income through voluntary actions.

B. Cooperatives and traditional companies with mutual purpose - that seek to reach the interests of its members and not a specific cause or mission.

2. In other types of organizations, which aim to achieve a social or environmental purpose, there is a business matrix with market-based strategies that legitimize private profit for the owner (s).

3. The social enterprise models previously mentioned are private entities and initiatives called "public sector spin-offs", "public statistics of tradition and purpose" and "provision of public services" respectively. Therefore, they indicate a public / state matrix in the scenario of references about social companies.

Typologies derived from the literature review, in a very deductive way, present differences and combinations of both mutual and general interest, which was important to draw a clearer image of the models of social enterprise.

According to Defourny and Nyssens (2017) there are three main distinct drivers that can be found in the global economy: general interest (IG), mutual interest (IM) and capital interest (IC), which directly derive the "benefit" Types theorized by Gui (1991).

Associations act through "mutual interest" (Gui, 1991) or "general interest". In the first case, there are voluntary organizations that seek the interests of their members, such as traditional cooperatives, for example. In the second case are voluntary and charitable organizations, among others, that seek public benefits for the communities they serve. In the second case these communities are not so large and, therefore, do not compete with state services.

On the right side of the triangle in Figure 4, it is possible to observe how the joint stock companies develop their RSE strategies. These actions express concern about topics of general interest, but do not question their profit motive. This can be a limited upward movement along that side of the triangle.

In that same Figure 4, the two dotted lines drawn in the triangle represent the various combinations types of resources (market revenue, public subsidies, philanthropic resources), distinguishing between market revenue or public funding dominates and those who prefer the combination of resources (hybrid resources) to balance their social mission and financial sustainability. 
The lower dotted line also divides the "mutual interest" angle: cooperatives are companies that operate in the market and appear below the line, as well as all companies that earn all or most of their market revenue; on the contrary, associations of mutual interest, such as sports clubs or other voluntary leisure organizations, depend on a mix of market resources (membership fees, sales at a bar or cafeteria) and other resources such as volunteering and public contributions in the form of exports, infrastructures and other indoor or outdoor installations (Defourny and Nyssens, 2017).

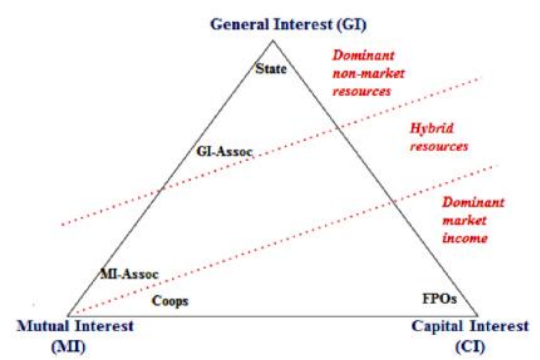

Figure 4. Principles of interest and resource mix

Source: Defourny and Nyssens (2017).

Based on the combination of inductive work (experimental typologies based on field observations), the more deductive conceptual construction of mutual benefit versus public benefit of Gui (1991) and the types of resources on which social companies depend, Defourny and Nyssens (2017) represented how several "institutional trajectories" across the economy can generate models of social entrepreneurship. Such institutional trajectories can be described as follows, represented in Figure 4:

1) Its "starting points" are the initial organizational types defined and located according to the three "principles of interest" in the triangle (Figure 4).

2) The trajectories themselves basically consist of one of the following movements:

a) An "upward" movement of organizations of mutual interest or capital interest (Assoc MI, Cooperatives, SMEs and Organizations with financial purposes) towards a behavior or strategy that gives more importance to the general interest in the social or corporate mission of the organization. This evolution is represented by blue arrows pointing upwards (blue being the color of the principles of interest) in Figure 4, or alternatively,

b) A "downward" movement from general interest organizations (based on non-market revenues or subsidized by public authorities) towards more market-oriented activities, as a complement to existing resources. In Figure 4 this evolution is represented by red arrows pointing downwards (red is the color of the resources). This change may involve the adoption of more commercial management methods.

3) Models of social entrepreneurship (in green) emerge from these institutional trajectories. Because they are still evolving, these models are not stable.

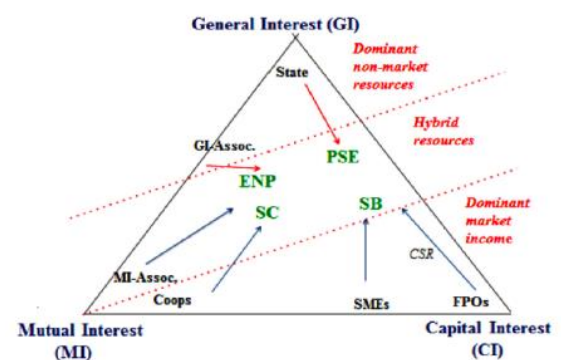

Figure 5. Institutional trajectories and resulting social business models

Source: Defourny and Nyssens (2017) 
As shown in Figure 5, six main distinct institutional trajectories (arrows in red and blue) were identified, resulting in four major models of social enterprises (written in green) non-profit business (ESFL), social cooperative (CS), social business (SB) and public sector (ESSP):

A. The non-profit business model (ESFL)

Non-profit organizations develop businesses in support of their social mission. Figure 5 suggest that earned income activities are more likely to be developed by IG Associations, which meet non-profit and in accordance with the general interest. They complement public donations and donations with new sources of funding. Represent any activity directed to the market and centered on the mission developed by a non-profit entity.

Earned income strategies can take several forms:

- Commercial activities not related to the mission whose surplus supports the social mission.

- Subsidiaries created by a non-profit organization to develop a commercial activity and generate profits to be returned to the parent company.

Non-profit corporate social enterprises can also result from the evolution of mutual interest associations (Associations-IM) to other associations that are more oriented towards the general interest.

B. The social cooperative model (CS)

The International Cooperative Alliance (ICA) defines a cooperative as follows: " A cooperative is an autonomous association of persons united voluntarily to meet their common economic, social and cultural needs and aspirations through a jointly owned and democratically controlled enterprise " (ICA, 2021).

Cooperatives are companies of mutual interest, democratically controlled by their members, in accordance with their non-capitalist interests. The social cooperative model arises with the interest of certain Cooperatives or Associations (IM) in working with models that favor the general interest.

This model of CS companies can also result from the evolution of associations of mutual interest that want to solve a specific social problem and start to develop their economic activities through the more explicit general interest. That is why the Associations IM arrow seems oriented towards both the non-profit model and the CS model.

C. The social business model (SB)

Business schools, consulting firms, social responsibility departments of large multinational corporations and various foundations consider social enterprises mission-oriented businesses. Does that promote comprehensive business methods and not income strategies as an efficient way to address social problems. It is important to emphasize that social companies carry out activities for social purposes or missions. As suggested in Figure 5, a stronger orientation towards the general interest can lead these "social businesses" to rely on a more hybrid economic model, with a greater proportion of non-market resources supporting, at least partially, goods or services provided for the "public good".

The definition of social business by Yunus involves more stringent conditions: "A social business is a company without losses, without dividends and based on the market, designed to meet a social objective" (Yunus, 2010).

In the typical capitalist economic system, an organization can either be considered as a profit-maximizing business, whose main purpose is to create value for its shareholders, or as a non-profit organization which addresses and solves social problems. However, a social business is a new form of business that can be located somewhere between a profit-maximizing and a non-profit organization (Ashraf et al., 2019).

D. The public sector social enterprise (ESSP) model

Social enterprises can emerge as "public sector spin-offs", thus meeting the demand of governments to reduce costs of providing public services to national and local levels. These companies create community businesses in underserved urban areas, employment and professional development opportunities for the disadvantaged unemployed, or take part of social services that are the responsibility of the state. They collaborate with the development of public policies.

The main motivation of the ESSP model is the "reconfiguration" or "externalization" of public services in the organizational form of the social enterprise, with the express objectives of improving and innovating.

\subsection{Social Innovation (SI)}

According to Murray et al. (2010), social innovation has no fixed limits, as it happens in all sectors, public, non-profit and private. In fact, many of the most creative actions are taking place at the borders between sectors, in fields as diverse as trade, distance learning, health, agriculture, waste reduction and justice. The growing interest in social 
innovation fits in with the broader trend of greater theoretical-innovative engagement with innovation phenomena in addition to the traditional focus on new technologies and products (Pel et al., 2020).

Social innovation is related to new products, services, and models aiming to improve human well-being and create social relationships and collaborations (Carayannis et al., 2019).

According to the bibliometric study conducted by Okano and Fernandes (2017), the results show that the publication of articles on social innovation in journals has increased over the past 20 years. From 2 articles in 1995 to 110 articles in 2015 (from 1995 to 2015) among the countries with the most articles, the United Kingdom, United States and Canada respectively occupy the first three, with 99 articles, 86 articles and 61 articles on social innovation. It is the UK's main contribution, with a total of 99 articles.

This theme is of interest to several areas of knowledge, although the greatest concentration is in social sciences, the other areas have also contributed with articles, characterizing that this is a multidisciplinary theme. Likewise, this topic is researched in several countries and teaching and research institutions in the world.

Several authors define social innovation and stand out:

Lévesque (2001) considers that social innovations are thought of as events in which new solutions are implemented in order to resolve a situation of social precariousness.

For Murray et al. (2010) definitions have their place, and our interest is in innovations that are social both in their ends and in their means. Specifically, we define social innovations as new ideas (products, services and models) that simultaneously meet social needs and create new social relationships or collaborations. In other words, they are innovations that are good for society and increase their capacity for action.

Gupta et al. (2019) present a more recent definition of social innovation: "Social innovation is a multidimensional construct encompassing a varied set of social actors collaborating for the social good, providing sustainable solutions for prevalent social issues, and building the social capital in the given community by bringing transformative changes in the society facilitated by technological capabilities".

\subsection{Business Model for Social Innovation}

The terms most used to define a business model (BM) are architecture, method or strategy that an organization or company uses to create value for its customer segment, in addition to the network of relationships and distribution with customers and suppliers (Okano, 2020A).

According to Carayannis et al. (2019) the business model innovation (BMI) context can foster social innovation and can be applied in social innovation projects and initiatives. Hybrid organizations like social purpose organizations frequently innovate their business models (BM) due to environmental constraints aiming to create social value while striving for economic viability (Klein et al., 2021).

Gasparin et al. (2020) report that the business model literature only considers how to meet customer needs and capture value from new technological products and services (Mongelli \& Rullani, 2017), describing the architecture of revenues, costs and profits associated with delivering value economic (Foss \& Saebi, 2017).

Business models offer a holistic view of the system level in business logic and also the possibility to focus on creating value in a comprehensive way (Zott, Amit and Massa, 2010).

Gasparin et al. (2020) propose a new approach to the SI business model that must take into account the sets of values and activities that an SI developing organization addresses and creates. The SI business model is designed to support the long-term growth of SMEs that develop SIs. Figure 6 presents an initial prototype of a business model for SI 


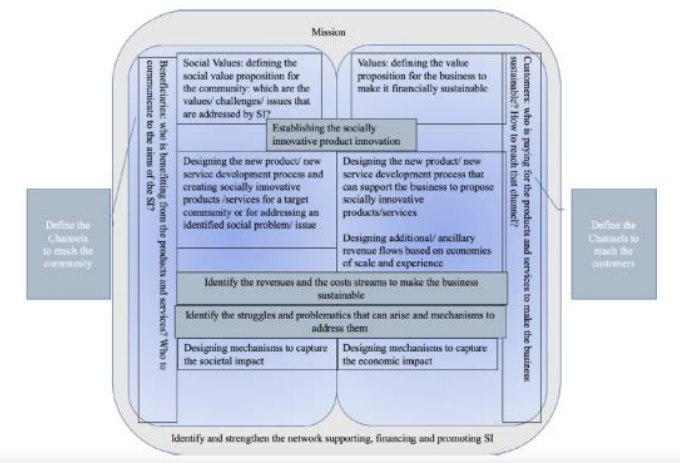

Figure 6. Business model for social innovation - Initial prototype

Source: Gasparin et al. (2020)

This first prototype was presented to a focus group composed of experts in the field and through the focus group dialogue, it was clear that the conceptualization of the model was ineffective and static.

It was suggested that the model did not reflect the dynamic and interactive approach needed to navigate in a very challenging environment, where the main motivations for organizations were social, ecological and cultural values. The business environments on which these types of organizations typically depend did not exist. Organizations needed a separation between economic and social, ecological and cultural values (although emphasized more clearly), but they also required separate prototyping, development and diffusion phases, since they required different resources. These comments were taken into account when developing the second (final) business model for SI, Figure 7 (Gasparin et al., 2020).

Based on the system of activities, Figure 7 presents the final business model for SI in an interactive process. The business model aims to provide a progressive approach, taking into account the stage of the SI development process, the use of the prototype and the level of monetization that the SI supports for the sustainable growth of the business.

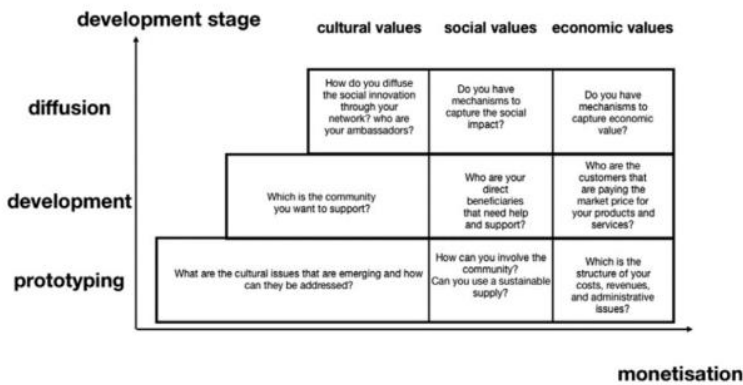

Figure 7. Business model for social innovation - Final Prototype

Source: Gasparin et al. (2020)

\section{Methodology}

This research project is qualitative, as according to Mascarenhas et al. (2012), qualitative research is useful when we want to increase the reliability and generalizability of the results and describe our object of study in greater depth. It can be classified as exploratory, because according to Mascarenhas et al. (2012), exploratory research is recommended for those who want to create more familiarity with a problem and then create hypotheses about it and in most cases, this study includes a bibliographic survey on the subject.

The first stage of the project was the elaboration of the theoretical framework through a bibliographic survey that addressed the themes social enterprise, typology of social enterprises, social business model and social innovation. 
The second stage consisted of preparing an interview script, which was our research instrument, based on the bibliographical survey on the types of social companies and on the social business model of Gasparin et al. (2020).

The next step was to select three social companies of different types to carry out the empirical research. The names of the companies have been kept confidential and their characteristics are as follows:

- Alfa was born from the need to supply peripheral neighborhoods in the Brasilândia region with an application-based transport service. When the best-known apps decided to block these regions, the founder saw an opportunity there and created in 2017 in Brasilândia and ran 3,000 races per month, with 170 drivers, almost all residents of the neighborhood. The service started simply: through a landline and a WhatsApp mobile phone, race orders are received, while drivers await the call in a waiting room.

- Beta is a non-profit cooperative that receives recyclable material through the selective collection of the city of Barueri or donations from companies or people, which it separates and sells to maintain its functioning. In 2002, the City Hall of Barueri installed selective collection in the municipality and on the land of the old dump, the city decided to close, land to become a landfill and take out garbage. The problem that arose was what to do with the old garbage collectors? So, the Cooperative was founded by former recyclable material collectors on the land of the old dump

- Gamma was a pioneering initiative by a large financial company, created in 2003, and for 15 years it stimulated the culture of giving in Brazil, fulfilled its cycle of success and ended its activities in December 2018. Through a fundraising platform of resources, which connected civil society organizations and their socio-environmental projects to social investors, making it possible to raise more than R \$ 19 million, destined for 190 projects from all over Brazil. His model inspired replications in South Africa, Portugal, England, Singapore and Jamaica.

The characteristics of the interviewees are shown in Table 2.

Table 2. Characteristics of the interviewees

\begin{tabular}{lll}
\hline Interviewee & Company & Office or function \\
\hline A1 & Alpha & CIO (founder) \\
\hline A2 & Alpha & CFO \\
\hline B1 & Beta & President \\
\hline B2 & Beta & Secretary \\
\hline G1 & Gamma & President (Founder) \\
\hline G2 & Gamma & Director \\
\hline
\end{tabular}

Source: Authors

The fourth step was to compare the results of the interviews with the theory through the typologies and the business model for social innovation and carry out the analyzes.

The last step was to write the research conclusions.

\section{Results and Analysis}

The results, obtained through interviews with the managers of social companies, were categorized according to their typologies of the theoretical framework and the business model for social innovation and are presented below:

\subsection{Typologies}

Table 3. Types of social enterprises according to the profit orientation

\begin{tabular}{lll}
\hline & Hybrid spectrum ( Alter , 2007) & Hybrid models ( Buchko, 2018 ) \\
\hline Alpha & Socially responsible businesses & Hybrid company \\
\hline Beta & Social enterprise & Social business \\
\hline Gamma & Corporation practicing social responsibility & Non-profit hybrid company
\end{tabular}

Source: Authors 
According to the typologies according to the profit orientation, the three companies received different classifications between them, but coherent between the Spectrum hybrid and Hybrid models.

The company Alfa is a hybrid social company, startup and a shared transport company with application that serves the residents of the neighborhood where the other companies do not work due to security problems. These characteristics classify the company Alfa as a socially responsible business, which according to Alter (2007), are for-profit companies that operate with dual objectives - profiting from their shareholders and contributing to a broader social good. It also classifies the company as a hybrid company, which according to Buchko (2018), the hybrid company is a mixture of the non-profit model and the profit model, being more financially self-sufficient.

Beta company is a non-profit cooperative that receives recyclable material through the selective collection of the city of Barueri or donations from companies or people, which it separates and sells to keep its operation. For Defourny and Nyssens (2017), cooperatives are organizations that seek the interests of their members and not a cause or mission. They aim at implementing forms of democratic governance, that is, equal voting power at the general meeting and limiting the remuneration of capital shares. According to Alter (2007), the Beta company is a social company, since social companies are defined as any commercial enterprise created for social purposes, mitigating / reducing a social problem or a market failure and to generate social value while operating with discipline financial, innovation and determination of a private sector business. On the other hand, Buchko (2018) classifies it as a social business, which carry out social and commercial business activities at the same time, are self-sustainable and more financially independent, thus being a profitable company contributing to a social good.

Gamma was a mission-driven social business that promoted business methods more widely (and not just income strategies) as an efficient way to address social problems. Gamma was a fundraising platform in the shape of a stock exchange. Safe, practical and transparent virtual donations environment, with total transfer of donated amounts for projects and complete accountability. The objective was to stimulate the culture of giving in Brazil, connecting two points: Brazilian organizations that need support for their socio-environmental projects and social investors. Beta can be classified as "corporation practicing social responsibility" and "non-profit hybrid company". Alter (2007) defines corporations practicing social responsibility as for-profit companies whose motives are financially motivated but are involved in philanthropy. "Strategic philanthropy" helps companies achieve the goals of maximizing profit and market share, contributing to the public good. Buchko (2018) classifies a non-profit hybrid company as a company that uses its available funds to support the operations of its own business, these funds coming from donation or philanthropy.

The typologies according to the profit orientation allowed to classify the three social companies surveyed according to their characteristics, including maintaining a theoretical coherence between the two authors Alter (2007) and Buchko (2018).

Table 4. Types of social enterprises according to business activities in social programs

\begin{tabular}{lll}
\hline & As for the mission ( Alter , 2007) & Business / program integration ( Alter , 2007) \\
\hline Alpha & Mission-Related Social Enterprise & Corporate social enterprises \\
\hline Beta & Mission-Related Social Enterprise & Integrated social enterprises \\
\hline Gamma & Mission-Centered Social Enterprise & Corporate social enterprises \\
\hline
\end{tabular}

According to Alter (2007) regarding mission, in hybrid organizations, money and mission are interconnected like DNA, but they are not always equal partners. In practice, financial and social goals are often in opposition or competition with each other.

The companies Alpha and Beta were classified as "Mission-Related Social Enterprise", as according to Alter (2007), mission-related social enterprises have synergistic properties, creating social value for programs and generating economic value to subsidize social programs and / or operating expenses of the organization. The services offered by Alfa are the social services themselves, the customers themselves are the beneficiaries, with no distinction between them. The company offers a shared transport service in areas where competitors do not attend due to security concerns. In the case of Beta, its mission is to "Collect and separate all recyclable material from the city of Barueri, in order to generate income for the families of our employees while helping to keep the environment cleaner and healthier", or that is, the generation of income is made through the sale of recyclable material and, therefore, they have synergistic properties to create value. 
Gamma was categorized as a Mission-Centered Social Company, where the company is central to the organization's social mission. These social companies are created with the express purpose of advancing the mission using a self-financing model (Alter, 2007). Gamma was a pioneering initiative by a large financial company, created in 2003, and for 15 years it stimulated the culture of giving in Brazil, fulfilled its cycle of success and ended its activities in December 2018. Through a fundraising platform resources, which connected civil society organizations and their socio-environmental projects to social investors, making it possible to raise more than $\mathrm{R} \$ 19$ million, destined for 190 projects across Brazil.

Business / program integration indicates that social enterprises can be classified based on the level of integration between social programs and business activities:

Alfa and Gamma were classified as Incorporated social companies, this classification is characterized by the social programs and business activities are the same, that is, the company's activities are "incorporated" into the organization's social operations and programs and are central to its mission (Alter, 2007). What differs between companies is that Alfa has its social activities financed by its own business activities and Gamma has its activities financed by a large financial corporation.

Beta was classified as an integrated social company, where social programs overlap with business activities, sharing costs and assets. Organizations create integrated social businesses as a financing mechanism to support the nonprofit's missionary operations and activities (Alter, 2007).

The typologies according to social companies according to business activities in the social programs allowed classifying the three social companies surveyed according to their characteristics.

Table 5. Types of social enterprises according to their origins, purposes and trajectories

\begin{tabular}{lll}
\hline & Source & Social business model \\
\hline Alpha & SMB (Startup) & Social business \\
\hline Beta & Cooperative & Social cooperative \\
\hline Gamma & Nonprofit organization & Non-profit business model (ESFL) \\
\hline
\end{tabular}

Source: Authors

In the study by Defourny \& Nyssens (2017), six main distinct institutional trajectories were identified, resulting in four major models of social enterprises: non-profit business (ESFL), social cooperative (CS), social business (SB) and public sector (ESSP). Table 5 presents the results of the companies based on the origin and the end of the trajectory as a social enterprise model.

The company Alfa is today an SMBand startup and in the classification of Defourny \& Nyssens (2017) it can be considered a social company, since social companies are companies that develop business activities for social purposes or missions. But when launched by for-profit companies, the "social entrepreneur" impulse consists of a move towards the general interest. Works emphasize a "double (or triple)" vision, and the creation of a "combined value". These characteristics were identified in the interviews with the founders as being a social entrepreneur, the dual mission challenge and the mission of the social value proposal.

Beta is a cooperative, that is, organizations that seek the interests of its members and not a cause or mission and aim to implement forms of democratic governance, that is, equal voting power at the general meeting and limiting the remuneration of capital shares (Defourny and Nyssens, 2017). Cooperatives are, first and foremost, companies of mutual interest, owned and (democratically) controlled by their members for their own non-capitalist interests. Defourny and Nyssens (2017) consider that natural evolution is for a model of social cooperative (CS), where it results from a movement of organizations of mutual interest (Cooperatives or IM Associations) towards a behavior that gives more importance to the general interest. Beta is still structuring itself and has the support of the Municipality of Barueri, the trajectory described by the authors Defourny and Nyssens (2017) were identified in the interviews of the cooperative's managers, where they reported that the cooperative will have to become professional and become a social enterprise.

Gamma was born as a non-profit organization maintained by a large financial company and for 15 years it stimulated the culture of giving in Brazil, fulfilled its cycle of success and ended its activities in 2018 as a non-profit business 
model (ESFL), which in Defourny and Nyssens (2017), are non-profit organizations that develop any type of income business in support of their social mission.

The typologies presented by Defourny and Nyssens (2017) could be used to classify the three social companies, including confirming the trajectories idealized by the interviewed managers.

\subsection{Business Model for Social Innovation}

To analyze the characteristics of the social companies surveyed, the Business Model for Social Innovation by Gasparin et al. (2020) in order to understand the relationships of these companies and social innovation. Table 6 presents the results.

Table 6. Business model for social innovation

\begin{tabular}{ll}
\hline Social values - Do you have mechanisms to capture the social impact? \\
\hline Alpha & $\begin{array}{l}\text { It is the rescue of the dignity of the resident to ask for a car and the car to pick it up or take it at } \\
\text { the door of their home. }\end{array}$ \\
\hline Beta & $\begin{array}{l}\text { The social value proposal is the social inclusion of the members. With job and income } \\
\text { generation for the cooperative members, Beta gives the chance of unemployed, ex-prisoners, } \\
\text { slum dwellers, homeless people, etc. having a job that generates a monthly income of R \$ } 1000 \\
\text { to R \$ } 1500.00, \text { two daily meals and an opportunity to regain dignity. }\end{array}$ \\
\hline Gamma & $\begin{array}{l}\text { The social value proposal is to allow the chosen organizations to serve low-income populations, } \\
\text { aiming to promote socioeconomic inclusion and to have projects in professional training, } \\
\text { citizenship, competence in reading and writing, cultural, health education, education for } \\
\text { sustainability, climate change, water resources, biodiversity and sustainable forests and cities. }\end{array}$ \\
\hline Values - Do you have mechanisms to capture economic value? \\
\hline Alpha & $\begin{array}{l}\text { The main value proposition is to offer decent transport to residents of Vila Brasilândia, since } \\
\text { other applications avoid it because the region is considered a risk area }\end{array}$ \\
\hline Beta & $\begin{array}{l}\text { The value proposal is to sell recycled material in large quantities from the selective collection } \\
\text { of Barueri to intermediaries and buyers }\end{array}$ \\
\hline Gamma & $\begin{array}{l}\text { The value proposal is to facilitate the meeting between Civil Society Organizations, carefully } \\
\text { selected, with relevant work and proven results in the area of education and entrepreneurship, } \\
\text { and socioenvironmental investors (donors) willing to support these organizations through the } \\
\text { purchase of their socioenvironmental actions. }\end{array}$
\end{tabular}

\begin{tabular}{ll}
\hline How do you spread social innovation on your network? Who are your ambassadors? \\
\hline Alpha & The main distribution channels are car stereo and pamphlets. The ambassadors are the drivers. \\
\hline Beta & $\begin{array}{l}\text { Respondents reported that the relationship takes place in a positive and direct way with } \\
\text { customers through city hall trucks or with the cooperative logo, through members, social } \\
\text { networks, WhatsApp and events. }\end{array}$ \\
\hline
\end{tabular}

\begin{tabular}{ll}
\hline Gamma & Through advertising and events. Artists and sponsors. \\
\hline Beneficiaries - Who are your direct beneficiaries who need help and support? \\
\hline Alpha & The beneficiary is also the client, the resident of Vila Brasilândia who needs decent transport. \\
\hline Beta & It is the cooperative or its worker, who are people facing social exclusion \\
\hline Gamma & $\begin{array}{l}\text { It is the CSO that has the approved socio-environmental project, that is, it receives the donation } \\
\text { from the client }\end{array}$ \\
\hline Customers - Who are the customers who are paying the market price for your products and services? \\
\hline Alpha & The customers are the residents of Vila Brasilândia. \\
\hline Beta & $\begin{array}{l}\text { Customers are the middlemen and companies that buy the recycled material. The main buyers } \\
\text { are the industries that recycle the materials or the manufacturers themselves. }\end{array}$ \\
\hline
\end{tabular}




\begin{tabular}{ll}
\hline Gamma & Clients are social donors who want to sponsor socio-environmental projects \\
\hline What community do you want to support? \\
\hline Alpha & $\begin{array}{l}\text { Brasilândia, also called Vila Brasilândia is a neighborhood belonging to the Brasilândia district } \\
\text { in the north of the municipality of São Paulo. }\end{array}$ \\
\hline Beta & $\begin{array}{l}\text { They are ex-garbage collectors, unemployed, ex-prisoners, slum dwellers, homeless, etc. from } \\
\text { Barueri }\end{array}$ \\
\hline Gamma & Civil society organizations
\end{tabular}

\begin{tabular}{ll}
\hline How can you involve the community? Can you use sustainable supply? \\
\hline Alpha & $\begin{array}{l}\text { Alfa offers a private transport application directed to the periphery, where other companies do } \\
\text { not serve and, because the drivers are from the region, they are the only ones who offer the } \\
\text { service and charge for the mileage. This business model has made Alfa a sustainable company }\end{array}$ \\
\hline Beta & $\begin{array}{l}\text { The community can assist in the separation of household waste for selective collection and also } \\
\text { in the donation of recyclable material. This recycled material is sold generating a sustainable } \\
\text { income. }\end{array}$ \\
\hline Gamma & $\begin{array}{l}\text { It works like a Stock Exchange, however, not for profit. In their environment, individuals and } \\
\text { institutions can donate resources to projects carefully selected for planning, documentation, } \\
\text { schedule and technical visits made by the team }\end{array}$
\end{tabular}

\begin{tabular}{ll}
\hline What is the structure of your costs, revenues and administrative issues? \\
\hline Alpha & $\begin{array}{l}\text { The cost structure consists of a headquarters in São Paulo, } 8 \text { employees, digital platforms, } \\
\text { drivers and the billing proceeds from } 10,000 \text { races. Administrative matters are resolved by the } \\
\text { partners. }\end{array}$ \\
\hline Beta & $\begin{array}{l}\text { The cost structure is made up of a warehouse, trucks, water and electricity are paid by the city. } \\
\text { Maintenance, cooperative, food, and other costs are maintained by the cooperatives. The costs } \\
\text { covered by the cooperative vary by } 30 \% \text { and } 40 \% \text { of the revenue amount. The cooperative's } \\
\text { revenue comes from the sale of recycled material. Administrative issues are resolved by a } \\
\text { board, democratically elected by the members. }\end{array}$ \\
\hline Gamma & $\begin{array}{l}\text { The cost structure is IT infrastructure, support staff, development team and employees. The } \\
\text { company receives financial support from its sponsor, as it has no revenue, in addition to } \\
\text { donations from customers, when it is unable to reach the necessary donations to cover } \\
\text { expenses. } \\
\text { Due to its commitment to the best corporate governance practices and believing that this is a } \\
\text { way of generating value, governance is managed by an Institute, in the form of a non-profit } \\
\text { association. }\end{array}$ \\
\hline What are the cultural issues that are arising and how can they be addressed? \\
\hline Alpha & $\begin{array}{l}\text { It is the rescue of the dignity of the resident to ask for a car and the car to pick it up or take it at } \\
\text { the door of their home. }\end{array}$ \\
\hline Beta & $\begin{array}{l}\text { Are reintegration into the job market and rescue citizenship and are addressed with job and } \\
\text { income opportunities }\end{array}$ \\
\hline Gamma & Development of socio-environmental projects with planning and management \\
\hline
\end{tabular}

Source: Authors

The business model for social innovation allowed verifying and understanding the main characteristics of the companies surveyed in relation to social innovation, concluding that the three social companies present social innovations in their business models. 


\section{Final Considerations}

The objective of the research was achieved and allowed to identify social companies by means of theoretical models and to analyze their characteristics to understand social innovation.

The theoretical framework, resulting from the literature review of this research, presented models and typologies of social companies based on Alter (2007), Buchko (2018) and Defourny \& Nyssens (2017). These typologies were tested in three social companies in the empirical research and the effectiveness of the typologies was proven.

The business model for social innovation by Gasparin et al. (2020) to verify and understand the characteristics of the three social companies in relation to social innovation, which was proven in the research results.

It can be concluded that social enterprises have a primary role in social innovations and play important roles in these scenarios. The main characteristics are dual mission (social and economic), have different roles as beneficiaries and customers, organizations with philanthropic purposes, etc.

As future work, it is possible to research a larger number of social companies, include new models and typologies and study the types of corporate governance. It is suggested to increase the number of research companies and other ways of analyzing the characteristics of social companies and social innovation.

\section{References}

Alter, K. (2007). Social enterprise typology. Virtue Ventures LLC, 12(1), 1-124.

Ashraf, M. M., Razzaque, M. A., Liaw, S. T., Ray, P. K., \& Hasan, M. R. (2019). Social business as an entrepreneurship model in emerging economy. Management Decision.

Bocken, N. (2021). Sustainable business models. In W. Leal Filho, U. Azeiteiro, A. M. Azul, L. Brandli, P. Özuyar, \& T. Wall (Eds.), Decent work and economic growth. Encyclopedia of the UN Sustainable Development Goals. Springer, Cham. https://doi.org/10.1007/978-3-319-95867-5_48

Buchko, T. (2018). Social entrepreneurship and its implications for Hungary. Periodica Polytechnica Social and Management Sciences, 26(1), 38-48. https://doi.org/10.3311/PPso.9376

Carayannis, E. G., Grigoroudis, E., Stamati, D., \& Valvi, T. (2019). Social business model innovation: A quadruple/quintuple helix-based social innovation ecosystem. IEEE Transactions on Engineering Management, 68(1), 235-248. https://doi.org/10.1109/TEM.2019.2914408

Choi, E., Kim, E., Kim, I., \& Choi, I. (2020). Attitude toward social enterprises: a comparison between for-profit and social enterprise employees. Sustainability, 12(7), 2720. https://doi.org/10.3390/su12072720

Dacin, P. A., Dacin, M. T., \& Matear, M. (2010). Social entrepreneurship: Why we don't need a new theory and how we move forward from here. Academy of Management Perspectives, 24(3), 37-57. https://doi.org/10.5465/amp.24.3.37

De Oliveira, N. D. A., \& Da Silva, T. N. (2012). Social innovation and sustainable social technologies inter-cooperatives relationships: an exploratory study in CREDITAG-RO. Revista de Administração da UFSM, 5(2), 277-295. https://doi.org/10.5902/198346595655

Dees, J. G. (1998). The meaning of social entrepreneurship.

Defourny, J., \& Borzaga, C. (2001). The emergence of social enterprise. Routledge. https://doi.org/10.4324/9780203164679

Defourny, J., \& Nyssens, M. (2017). Fundamentals for an international typology of social enterprise models. Voluntas: International Journal of Voluntary and Nonprofit Organizations, 28(6), 2469-2497. https://doi.org/10.1007/s11266-017-9884-7

Foss, N. J., \& Saebi, T. (2017). Fifteen years of research on business model innovation: How far have we come, and where should we go?. Journal of Management, 43(1), 200-227. https://doi.org/10.1177/0149206316675927

Gasparin, M., Green, W., Lilley, S., Quinn, M., Saren, M., \& Schinckus, C. (2021). Business as unusual: A business model for social innovation. Journal of Business Research, 125, 698-709. https://doi.org/10.1016/j.jbusres.2020.01.034

Granados, M. L., Hlupic, V., Coakes, E., \& Mohamed, S. (2011). Social enterprise and social entrepreneurship research and theory: A bibliometric analysis from 1991 to 2010. Social Enterprise Journal, 7(3). https://doi.org/10.1108/17508611111182368 
Gui, B. (1991). The economic rationale for the "Third Sector". Annals of Public and Cooperative Economics, 62(4), 551-572. https://doi.org/10.1111/j.1467-8292.1991.tb01367.x

Gupta, S., Kumar, V., \& Karam, E. (2019). New-age technologies-driven social innovation: What, how, where, and why?. Industrial Marketing Management, 89, 499-516. https://doi.org/10.1016/j.indmarman.2019.09.009

ICA. (2021). What is a cooperative. Retrieved March 15, 2021, from https://www.ica.coop/en/cooperatives/what-is-a-cooperative

Klein, S., Schneider, S., \& Spieth, P. (2021). How to stay on the road? A business model perspective on mission drift in social purpose organizations. Journal of Business Research, 125, 658-671. https://doi.org/10.1016/j.jbusres.2020.01.053

Lévesque, B. (2002). Les entreprises d'économie sociale, plus porteuses d'innovations sociales que les autres?. CRISES, Université du Québec à Montréal.

Mascarenhas, S. A., et al.. (2012). Metodologia científica.

Mongelli, L., \& Rullani, F. (2017). Inequality and marginalization: social innovation, social entrepreneurship and business model innovation: The common thread of the DRUID Summer Conference 2015. Industry and Innovation, 24(5), 446-467. https://doi.org/10.1080/13662716.2017.1295365

Mulgan, G. (2010). Measuring social value. Stanford Social Innovation Review, 8(3), 38-43.

Murray, R., Caulier-Grice, J., \& Mulgan, G. (2010). The open book of social innovation (Vol. 24). London: Nesta.

Okano, M. T. (2017). Interorganisational networks and social innovation: a study in milk production chain. International Journal of Innovation and Sustainable Development, 11(4), 317-335. https://doi.org/10.1504/IJISD.2017.086868

Okano, M. T. (2020A). A contribuição das Tecnologias da Informação e Comunicação (TICs) para a criação de valor nas empresas sociais. Doctoral dissertation. https://doi.org/10.33448/rsd-v9i3.2435

Okano, M. T. (2020B). Análise bibliométrica das empresas sociais: qual o seu impacto na produção acadêmica?. Research, Society and Development, 9(3), e73932435-e73932435.

Okano, M., \& Eloy Fernandes, M. (2017). A importancia da inovação social no contexto atual: uma pesquisa bibliometrica sobre a produção acadêmica dos últimos 20 anos. Resumo, Anais Uninove.

Pel, B., Haxeltine, A., Avelino, F., Dumitru, A., Kemp, R., Bauler, T., ... Jørgensen, M. S. (2020). Towards a theory of transformative social innovation: A relational framework and 12 propositions. Research Policy, 49(8), 104080. https://doi.org/10.1016/j.respol.2020.104080

Sunio, V., Laperal, M., \& Mateo-Babiano, I. (2020). Social enterprise as catalyst of transformation in the micro-mobility sector. Transportation Research Part A: Policy and Practice, 138, 145-157. https://doi.org/10.1016/j.tra.2020.05.027

Tykkyläinen, S., \& Ritala, P. (2021). Business model innovation in social enterprises: An activity system perspective. Journal of Business Research, 125, 684-697. https://doi.org/10.1016/j.jbusres.2020.01.045

Yunus, M. (2010). Building social business: The new kind of capitalism that serves humanity's most pressing needs. PublicAffairs.

Zott, C., Amit, R., \& Massa, L. (2011). The business model: recent developments and future research. Journal of Management, 37(4), 1019-1042. https://doi.org/10.1177/0149206311406265

\section{Copyrights}

Copyright for this article is retained by the author(s), with first publication rights granted to the journal.

This is an open-access article distributed under the terms and conditions of the Creative Commons Attribution license (http://creativecommons.org/licenses/by/4.0/). 